\title{
FERTILISER VALUE AND TRACE ELEMENT CONTENT OF COMPOSTS PRODUCED FROM DIFFERENT WASTES
}

\author{
Edward Meller', Edward Niedźwiecki' ${ }^{1}$, Patrycja Rogalska², \\ Grzegorz Jarnuszewski' ${ }^{1}$ Dawid Wilczyński ${ }^{1}$
}
1 Department of Soil Science, Grassland and Environmental Chemistry, West Pomeranian University of Techno- logy, Słowackiego 17, 71-434 Szczecin, Poland, e-mail: edward.meller@zut.edu.pl; edward.niedzwiecki@zut. edu.pl; grzegorz.jarnuszewski@zut.edu.pl
2 Renewable Energy Research and Training Centre, Ostoja 10, 72-001 Kołbaskowo, Poland, e-mail: patrycja. rogalska@zut.edu.pl

Received: 2015.06 .06

Accepted: 2015.08.31

Published: 2015.10.01

\begin{abstract}
Composting process provides a valuable material improving physical and chemical properties of soil. The quality of the obtained compost depends to a great extent on the kind of material subjected to stabilisation. Composting biodegradable products may result in the end product exceeding heavy metal limits that cannot be used in agriculture. The studies included composts produced in the compost plant in Kołobrzeg, the Municipal Waste Recovery and Storage Plant in Leśno Górne and the Waste Managemant Plant in Wardyń Górny. Composts were made from municipal solid waste, sewage sludge with straw and sawmill waste, and from urban green waste. The following determinations were determined: morphological composition, total content of macroelements and microelements and the level of these elements soluble in $\mathrm{HCl}$ at the concentration of $0.5 \mathrm{~mol} \cdot \mathrm{dm}^{-3}$. The examined composts contained the amounts of total $\mathrm{Pb}, \mathrm{Ni}$ and $\mathrm{Cd}$ allowing for their use in agriculture and the compost from sewage sludge, straw and sawmill waste, turned out to have the best utilisation properties.
\end{abstract}

Keywords: compost, municipal waste, sewage sludge, biodegradable wastes, fertiliser values, heavy metals.

\section{INTRODUCTION}

Composting is a low temperature bio-oxidative process of organic matter transformation and belongs to important trends in recycling organic and mineral components of wastes [Baran et al. 2009]. Currently, in Poland attempts are made to reduce the amount of biodegradable waste deposited on landfills. Organic recycling, including composting of biodegradable wastes may be one of the ways to achieve this goal. In the case of municipal wastes this method is extremely advantageous since it eliminates their sanitary-epidemiological hazard and reduces the organic content of landfills. Among other advantages of the method, there are its availability, easy exploitation and the possibil- ity of obtaining soil amendment improving its fertility [Manczarski 2009, Pagans et al. 2006, Zhao et al. 2013]. Biodegradable wastes from various streams constitute a valuable material for biological, both aerobic and anaerobic, treatment technologies. However, a decisive criterion for the usefulness of the product is its quality [Jędrczak and Haziak 2005]. The product obtained as a result of composting municipal waste and sewage sludge is rich in humus and macro and microelements [Jasiewicz et al. 2010]. The only problem is the increase in heavy metal content [Gondek and Kopeć, 2012, Miaomiao et al. 2009]. High concentration of heavy metals in obtained product may exclude the possibility of their use in agriculture [Jasiewicz et al. 2010], especially those produced 
from municipal waste [Castaldi et al. 2006, Sądej and Namiotko 2010].

The purpose of this research was to evaluate and compare the fertiliser value and heavy metal content of compost produced from different initial materials.

\section{MATERIALS AND METHODS}

The study was conducted on 25 samples of mature composts. Ten of them were from the compost plant in Kołobrzeg, producing compost from municipal waste. The other 10 were the samples of compost from biodegradable waste from Szczecin cemetery, which are collected by the Waste Recovery and Storage Plant in Leśno Górne. The remaining 5 samples came from the Waste Treatment Plant in Wardyń Górny, from the compost produced from sewage sludge $(30 \%)$ mixed with sawmill waste and straw (70\%). Samples were taken by drilling piles at different sites. After air-drying, initially prepared material was crushed in the mortar to pass a 1.0-mm mesh sieve. Next, the weight of each fraction was determined. The fraction over $1.0 \mathrm{~mm}$ was separated into unprocessed organic parts, stones, gravel, glass and plastics. On the basis of the weight of separated morphological components their percentages were calculated. Unprocessed organic matter was shredded and included into particles below $1.0 \mathrm{~mm}$. Fine earth fraction $(<1.0 \mathrm{~mm})$ was subjected to further laboratory analysis.

Loss-on-ignition was determined at the temperature $550{ }^{\circ} \mathrm{C}, \mathrm{pH}$ in $\mathrm{KCl}, \mathrm{H}_{2} \mathrm{O}$ potentiometrically, $\mathrm{C}, \mathrm{N}$ and $\mathrm{S}$ content using an elementary analyser and gas chromatography. The content of macroelements $\mathrm{P}, \mathrm{K}, \mathrm{Mg}, \mathrm{Ca}, \mathrm{Na}$ was determined in $\mathrm{HCl}$ at the concentration $0.5 \mathrm{~mol} \cdot \mathrm{dm}^{3}$ and the mixture of concentrated $\mathrm{HNO}_{3}+\mathrm{HClO}_{4}$, phosphorus content colorimetrically, $\mathrm{K}$ and $\mathrm{Na}$ by flame photometry, and $\mathrm{Ca}$ and $\mathrm{Mg}$ by atomic absorption spectrometry. Fine earth was analysed for heavy metal content ( $\mathrm{Fe}, \mathrm{Mn}, \mathrm{Zn}, \mathrm{Cu}, \mathrm{Pb}, \mathrm{Ni}, \mathrm{Co}, \mathrm{Cd}$ ). The content of trace elements soluble in $\mathrm{HCl}$ at the concentration $0.5 \mathrm{~mol} \cdot \mathrm{dm}^{-3}$, and also after wet mineralization in the mixture of concentrated $\mathrm{HNO}_{3}+\mathrm{HClO}_{4}$, were obtained by means of atomic absorption spectrophotometer.

\section{RESULTS}

Examined composts were characterised by varied amount of fine earth, unprocessed organic residues, gravel, stones, plastics and glass (Table 1). The highest fine earth percentage $71.45 \%$ was found in the compost from the waste from the urban green areas. The lowest percentage of the fraction below $1.0 \mathrm{~mm}$ was detected in the compost from municipal waste $-48.79 \%$, on average. The compost from sewage sludge, sawmill waste and straw contained $52.31 \%$ of the above mentioned fraction. In the case of unprocessed organic parts the highest mean percentage was observed in the compost produced by the Waste Treatment Plant in Wardyń Górny $-27.26 \%$, and the lowest in that one from the Waste Recovery and Storage Plant in Leśno Górne - 1.34\%.

The compost from the compost plant in Kołobrzeg contained on average $7.42 \%$ of unprocessed organic parts. Mean content of gravel and stones was at the level of the compost from municipal waste $-9.62 \%$, for the compost from the urban green areas $-16.14 \%$. The highest amount of gravel and stones was recorded in the compost from sewage sludge $-20.43 \%$. Such morphological components as plastics and glass have not been selected from the samples of the compost produced from sewage sludge, sawmill waste and straw. However, these components were separated from the compost from the waste of city green areas $(1.60 \%$ plastics and $9.47 \%$ glass on average) and the compost from municipal solid waste $(11.10 \%$ plastics and $23.07 \%$ glass).

Analysing the properties of composts originating from different sources (Table 2), it can be noticed that the reaction of sewage sludge ( $\mathrm{pH}$ in $\mathrm{H}_{2} \mathrm{O}$ in the range 5.31-6.40) considerably differs from the reaction of composts from municipal waste and green waste $\left(\mathrm{pH}\right.$ in $\mathrm{H}_{2} \mathrm{O}$ in the range $6.72-7.82$ and 6.88-7.09, respectively). Sewage sludge compost contained $45.59 \%$ of organic matter, municipal waste compost $35.54 \%$, and green waste compost $9.00 \%$, on average. $\mathrm{N}$ content in the analysed compost ranged from $0.36 \%$ (green waste compost) to $2.13 \%$ (sewage sludge compost). $\mathrm{C}: \mathrm{N}$ ratio was; 11.31 in the compost from sewage sludge, 12.76 in the compost from municipal waste and 15.18 in that from the green waste. The highest content of organic $\mathrm{C}$ and total forms of $\mathrm{N}, \mathrm{P}, \mathrm{K}, \mathrm{Mg}$ was found in sewage sludge compost, whereas the lowest amount of these elements in green waste compost. The latter contained also the least of total S, Ca and $\mathrm{Na}$, and the former the most of them (Table 2). 
Table 1. Percentage share of separated compost components

\begin{tabular}{|c|c|c|c|c|c|}
\hline \multirow{2}{*}{ Value } & Fraction $<1.0 \mathrm{~mm}$ & $\begin{array}{c}\text { Weakly transformed } \\
\text { organic matter }\end{array}$ & Gravel. stones & Plastics & Glass \\
\hline & \multicolumn{5}{|c|}{ [\%] } \\
\hline \multicolumn{6}{|c|}{ Compost from sewage sludge } \\
\hline $\min$. & 50.38 & 24.42 & 17.21 & - & - \\
\hline $\max$. & 55.79 & 29.61 & 22.80 & - & - \\
\hline mean & 52.31 & 27.26 & 20.43 & - & - \\
\hline$S$ & 2.25 & 1.89 & 2.18 & - & - \\
\hline \multicolumn{6}{|c|}{ Municipial solid waste compost } \\
\hline $\min$. & 45.18 & 3.24 & 7.02 & 9.65 & 20.63 \\
\hline $\max$. & 52.77 & 9.42 & 11.19 & 11.97 & 25.16 \\
\hline mean & 48.79 & 7.42 & 9.62 & 11.10 & 23.07 \\
\hline$S$ & 3.04 & 1.77 & 1.45 & 0.73 & 1.65 \\
\hline \multicolumn{6}{|c|}{ Green waste compost } \\
\hline $\min$. & 66.40 & 0.40 & 12.06 & 0.76 & 7.05 \\
\hline $\max$. & 78.42 & 2.84 & 19.92 & 3.50 & 12.56 \\
\hline mean & 71.45 & 1.34 & 16.14 & 1.60 & 9.47 \\
\hline$S$ & 3.43 & 0.83 & 3.02 & 0.86 & 1.54 \\
\hline
\end{tabular}

Table 2. Some physico-chemical and chemical properties of examined composts (total $\mathrm{P}, \mathrm{K}, \mathrm{Mg}, \mathrm{Ca}$ and $\mathrm{Na}$ soluble in concentrated $\mathrm{HNO}_{3}+\mathrm{HClO}_{4}$ )

\begin{tabular}{|c|c|c|c|c|c|c|c|c|c|c|c|c|}
\hline \multirow{2}{*}{ Value } & \multicolumn{2}{|c|}{$\mathrm{pH}$} & \multirow{2}{*}{$\begin{array}{c}\begin{array}{c}\text { Organic } \\
\text { matter }\end{array} \\
{[\%]}\end{array}$} & C & $\mathrm{N}$ & $S$ & \multirow{2}{*}{ C:N } & $P$ & $\mathrm{~K}$ & $\mathrm{Mg}$ & $\mathrm{Ca}$ & $\mathrm{Na}$ \\
\hline & $\mathrm{H}_{2} \mathrm{O}$ & $\mathrm{KCl}$ & & \multicolumn{3}{|c|}{$\left[\mathrm{g}^{\mathrm{kg}} \mathrm{g}^{-1}\right]$} & & \multicolumn{5}{|c|}{$\left[g^{\prime} \mathrm{kg}^{-1}\right]$} \\
\hline \multicolumn{13}{|c|}{ Compost from sewage sludge } \\
\hline $\min$. & 5.31 & 4.96 & 39.72 & 212.99 & 18.30 & 4.80 & 10.71 & 4.80 & 13.73 & 4.67 & 26.90 & 0.83 \\
\hline $\max$. & 6.40 & 5.84 & 51.33 & 261.66 & 23.49 & 7.06 & 11.90 & 6.20 & 18.08 & 5.46 & 38.54 & 2.95 \\
\hline mean & - & - & 45.59 & 239.98 & 21.30 & 6.16 & 11.31 & 5.26 & 16.17 & 4.94 & 31.34 & 1.82 \\
\hline$S$ & - & - & 5.46 & 22.09 & 2.61 & 1.19 & 0.47 & 0.56 & 1.18 & 0.38 & 6.84 & 0.86 \\
\hline \multicolumn{13}{|c|}{ Municipial solid waste compost } \\
\hline $\min$. & 6.72 & 6.53 & 31.35 & 189.59 & 15.77 & 2.76 & 11.74 & 2.44 & 2.85 & 2.39 & 63.33 & 2.84 \\
\hline $\max$. & 7.89 & 6.83 & 39.87 & 233.17 & 18.75 & 9.37 & 14.65 & 3.67 & 6.89 & 3.24 & 78.90 & 15.77 \\
\hline mean & - & - & 35.54 & 212.60 & 16.69 & 6.08 & 12.76 & 2.96 & 4.73 & 2.94 & 71.26 & 7.62 \\
\hline$S$ & - & - & 3.02 & 12.98 & 0.92 & 1.97 & 0.88 & 0.35 & 1.00 & 0.27 & 14.25 & 1.42 \\
\hline \multicolumn{13}{|c|}{ Green waste compost } \\
\hline $\min$. & 6.88 & 6.56 & 7.36 & 44.13 & 3.03 & 0.39 & 14.44 & 0.73 & 1.79 & 1.19 & 9.11 & 0.23 \\
\hline $\max$. & 7.09 & 6.82 & 11.41 & 67.65 & 4.36 & 0.74 & 16.46 & 0.92 & 2.66 & 1.74 & 14.99 & 0.38 \\
\hline mean & - & - & 9.00 & 53.97 & 3.55 & 0.56 & 15.18 & 0.82 & 2.29 & 1.36 & 12.44 & 0.32 \\
\hline$S$ & - & - & 1.31 & 8.13 & 0.42 & 0.11 & 0.60 & 0.06 & 0.24 & 0.18 & 1.45 & 0.04 \\
\hline
\end{tabular}

Mean concentration of phosphorus converted to oxide form amounted to $1.21 \%$ in sewage sludge compost, $0.68 \%$ in municipal solid waste compost and $0.19 \%$ in green waste compost Mean content of potassium (Table 2) converted to oxide forms was as follows: $1.95 \%$ in sewage sludge compost, $0.57 \%$ in municipal waste compost and $0.26 \%$ in green waste compost.
Similarly to the total level of $\mathrm{P}, \mathrm{K}, \mathrm{Mg}$, the highest level of these elements soluble in $\mathrm{HCl}$ at the concentration $0.5 \mathrm{~mol} \cdot \mathrm{dm}^{3}$, was observed in sewage sludge compost (Table 3 ). The lowest concentration of $\mathrm{P}, \mathrm{K}, \mathrm{Mg}, \mathrm{Ca}$ and $\mathrm{Na}$ soluble in $\mathrm{HCl}$ at the concentration $0.5 \mathrm{~mol}^{\cdot} \mathrm{dm}^{3}$ was recorded in green waste compost. Sewage sludge, however, had the highest level of $\mathrm{Ca}$ and $\mathrm{Na}$. 
Table 3. Content of macroelements soluble in $\mathrm{HCl}$ at the concentration $0.5 \mathrm{~mol} \cdot \mathrm{dm}^{-3}$ in examined composts

\begin{tabular}{|c|c|c|c|c|c|}
\hline \multirow{2}{*}{ Value } & $P$ & $\mathrm{~K}$ & $\mathrm{Mg}$ & $\mathrm{Ca}$ & $\mathrm{Na}$ \\
\hline & \multicolumn{5}{|c|}{$\left[\mathrm{g} \cdot \mathrm{kg}^{-1}\right]$} \\
\hline \multicolumn{6}{|c|}{ Compost from sewage sludge } \\
\hline $\min$. & 1.32 & 12.81 & 3.99 & 19.5 & 0.65 \\
\hline $\max$. & 1.42 & 17.30 & 5.22 & 35.4 & 2.56 \\
\hline mean & 1.37 & 15.21 & 4.74 & 28.5 & 1.36 \\
\hline$S$ & 0.04 & 2.15 & 0.60 & 7.9 & 0.73 \\
\hline \multicolumn{6}{|c|}{ Municipial solid waste compost } \\
\hline $\min$. & 0.86 & 2.73 & 1.74 & 56.8 & 1.77 \\
\hline $\max$. & 1.36 & 6.73 & 2.46 & 72.3 & 11.01 \\
\hline mean & 1.15 & 4.55 & 2.20 & 67.6 & 4.37 \\
\hline S & 0.18 & 1.36 & 0.24 & 5.2 & 2.72 \\
\hline \multicolumn{6}{|c|}{ Green waste compost } \\
\hline $\min$. & 0.34 & 0.92 & 0.51 & 8.86 & 0.14 \\
\hline $\max$. & 0.55 & 1.65 & 0.73 & 13.7 & 0.30 \\
\hline mean & 0.42 & 1.26 & 0.59 & 11.2 & 0.23 \\
\hline$S$ & 0.06 & 0.19 & 0.08 & 1.3 & 0.05 \\
\hline
\end{tabular}

Table 4. Content of trace elements soluble in concentrated $\mathrm{HNO}_{3}+\mathrm{HClO}_{4}$ in examined composts

\begin{tabular}{|c|c|c|c|c|c|c|c|c|}
\hline \multirow{2}{*}{ Value } & $\mathrm{Fe}$ & $\mathrm{Mn}$ & $\mathrm{Zn}$ & $\mathrm{Cu}$ & $\mathrm{Pb}$ & $\mathrm{Ni}$ & Co & $\mathrm{Cd}$ \\
\hline & \multicolumn{8}{|c|}{$\left[\mathrm{mg} \cdot \mathrm{kg}^{-1}\right]$} \\
\hline \multicolumn{9}{|c|}{ Compost from sewage sludge } \\
\hline $\min$. & 7995 & 320.6 & 470.0 & 86.8 & 14.5 & 11.33 & 1.11 & 0.934 \\
\hline max. & 9625 & 485.8 & 993.6 & 96.9 & 20.2 & 12.97 & 2.26 & 2.843 \\
\hline mean & 8923 & 390.8 & 721.4 & 93.4 & 17.0 & 11.82 & 1.53 & 2.313 \\
\hline$S$ & 635 & 60.7 & 13.6 & 4.0 & 2.4 & 0.67 & 0.43 & 0.084 \\
\hline \multicolumn{9}{|c|}{ Municipial solid waste compost } \\
\hline $\min$. & 4871 & 140.2 & 373.0 & 76.6 & 52.9 & 16.55 & 2.15 & 1.103 \\
\hline max. & 11095 & 284.2 & 691.8 & 249.6 & 138.9 & 30.03 & 4.48 & 3.415 \\
\hline mean & 7516 & 181.6 & 487.6 & 122.4 & 81.8 & 22.12 & 3.17 & 1.826 \\
\hline S & 2066 & 33.2 & 132.2 & 50.0 & 29.8 & 5.42 & 0.60 & 0.779 \\
\hline \multicolumn{9}{|c|}{ Green waste compost } \\
\hline $\min$. & 5865 & 138.1 & 66.9 & 17.4 & 15.0 & 6.70 & 1.56 & 0.168 \\
\hline max. & 8550 & 190.9 & 162.1 & 28.5 & 39.2 & 9.34 & 2.63 & 1.233 \\
\hline mean & 6650 & 159.1 & 89.7 & 21.7 & 21.8 & 7.60 & 2.04 & 0.662 \\
\hline$S$ & 933 & 19.6 & 22.8 & 3.5 & 7.2 & 0.98 & 0.32 & 0.37 \\
\hline
\end{tabular}

The comparison of total heavy metal content in different composts (Table 4) shows the highest mean content of $\mathrm{Fe}, \mathrm{Mn}, \mathrm{Zn}$ and $\mathrm{Cd}$, and the lowest of $\mathrm{Pb}$ and $\mathrm{Co}$ in sewage sludge compost. The green waste compost was characterised by the lowest content of total $\mathrm{N}, \mathrm{Fe}, \mathrm{Mn}, \mathrm{Zn}, \mathrm{Cu}, \mathrm{Cd}$ and $\mathrm{Ni}$, whereas municipal solid waste compost had the highest mean content of total $\mathrm{Cu}, \mathrm{Pb}, \mathrm{Ni}$ and $\mathrm{Co}$.

Analysing the concentration of determined trace elements soluble in $\mathrm{HCl}$ at the concen- tration $0.5 \mathrm{~mol} \cdot \mathrm{dm}^{-3}$ a slightly different distribution of mean highest and lowest values was found than in the case of their total forms (Table 5). The largest amounts of Fe, Mn, Zn and $\mathrm{Cd}$ soluble in $\mathrm{HCl}$ at the concentration $0.5 \mathrm{~mol} \cdot \mathrm{dm}^{-3}$ were recorded in sewage sludge compost which, simultaneously, contained the least of $\mathrm{Cu}, \mathrm{Pb}, \mathrm{Ni}$ and $\mathrm{Co}$. Compost from municipal solid waste had the highest amount of the described form of $\mathrm{Cu}, \mathrm{Pb}, \mathrm{Ni}$ and the 
Table 5. Content of trace elements soluble in $\mathrm{HCl}$ at the concentration $0.5 \mathrm{~mol} \cdot \mathrm{dm}^{-3}$ in examined composts

\begin{tabular}{|c|c|c|c|c|c|c|c|c|}
\hline \multirow{2}{*}{ Value } & $\mathrm{Fe}$ & $\mathrm{Mn}$ & $\mathrm{Zn}$ & $\mathrm{Cu}$ & $\mathrm{Pb}$ & $\mathrm{Ni}$ & Co & $\mathrm{Cd}$ \\
\hline & \multicolumn{8}{|c|}{$\left[\mathrm{mg} \cdot \mathrm{kg}^{-1}\right]$} \\
\hline \multicolumn{9}{|c|}{ Compost from sewage sludge } \\
\hline $\min$. & 2443 & 284.3 & 463.1 & 0.451 & 0.811 & 0.169 & 0.050 & 1.735 \\
\hline max. & 6468 & 434.6 & 985.6 & 7.089 & 8.140 & 2.121 & 0.667 & 2.416 \\
\hline mean & 3776.2 & 365.88 & 676.98 & 3.296 & 5.049 & 1.203 & 0.357 & 2.015 \\
\hline $\mathrm{s}$ & 1769.24 & 71.99 & 272.58 & 2.763 & 3.867 & 0.949 & 0.286 & 0.267 \\
\hline \multicolumn{9}{|c|}{ Municipial solid waste compost } \\
\hline $\min$. & 876 & 132.9 & 327.8 & 9.962 & 28.15 & 5.878 & 0.419 & 0.879 \\
\hline $\max$. & 2078 & 250.5 & 589.5 & 48.39 & 64.40 & 12.50 & 1.752 & 2.348 \\
\hline mean & 1360.7 & 163.83 & 444.57 & 24.210 & 40.68 & 7.49 & 0.76 & 1.64 \\
\hline$S$ & 414.41 & 35.63 & 95.82 & 13.96 & 14.27 & 2.196 & 0.389 & 0.577 \\
\hline \multicolumn{9}{|c|}{ Green waste compost } \\
\hline $\min$. & 1160 & 127.8 & 52.9 & 9.487 & 14.62 & 0.967 & 0.841 & 0.118 \\
\hline $\max$ & 2130 & 172.0 & 147.1 & 15.45 & 18.54 & 1.639 & 1.214 & 0.966 \\
\hline mean & 1475.2 & 141.34 & 67.23 & 11.465 & 15.852 & 1.290 & 1.015 & 0.523 \\
\hline S & 298.74 & 13.97 & 28.52 & 1.78 & 1.16 & 0.24 & 0.12 & 0.29 \\
\hline
\end{tabular}

lowest amount of Mn and $\mathrm{Zn}$ (Table 5). In the compost from urban green waste there was the most $\mathrm{Co}$ and the least $\mathrm{Mn}, \mathrm{Zn}$ and Cd soluble in $\mathrm{HCl}$ at the concentration $0.5 \mathrm{~mol} \cdot \mathrm{dm}^{-3}$.

\section{DISCUSSION}

As far as undesirable components, such as glass and plastics, are concerned, the best properties were detected in sewage sludge compost, while a high amount of glass in the compost from city green waste excluded from agricultural use. Ciesielczuk et al. [2011] point to a considerable amount of glass in compost produced from municipal solid waste. The reaction of examined compost made from sewage sludge, straw and sawmill waste is similar to the results obtained by Czekała and Sawicka [2006] for the compost from sewage sludge with different share of straw and sawdust. Lower $\mathrm{pH}$ in sewage sludge compost in comparison with municipal solid waste compost, was also reported by Lisk et al. [1992]. Alkaline reaction of compost from municipal waste was obtained by Kazanowska and Szaciło [2008], Raj and Antil [2010] as well as Zao et al. [2013], and in compost from green waste Beesley and Dickinson [2010]. However, composts investigated by Krzywy-Gawrońska [2010] from sewage sludge with varying amounts of green waste, straw and coal ash were characterised by alkaline reaction.
According to the Act on Fertilisers and Fertilisation [Dz. U. 2007, No 147, item 1033] and the Regulation of the Minister of Agriculture and Rural Development [Dz. U. 2008, No 119, item 765], the examined composts manufactured from sewage sludge and municipal waste meet the requirements in terms of organic matter content $\geq 30 \%$ for organic fertilisers in solid form. Many authors' papers confirm [Lisk et al. 1992, Kazanowska and Szaciło, 2008, KrzywyGawrońska, 2010, Kosobudzki et al. 2000, Ribeiro et al. 1996] a substantial content of organic matter in composts produced from sewage sludge and municipal solid waste. On the other hand, the compost from urban green waste does not conform to the minimum content of organic matter for organic and organic-mineral fertilisers in a solid form, given in the regulations [Dz. U. 2008, No 119, item 765]. All examined composts with the content of total $\mathrm{N}>0.3 \%$ meet the requirement of minimum $\mathrm{N}$ content in accordance with the Regulation [Dz. U. 2008, No 119, item 765] similarly to the composts described by KrzywyGawrońska [2010]. The obtained C:N ratio, from 11.3 to 15.8 , prove the maturity of the product generated as a result of biological, aerobic transformation of biodegradable wastes. In many authors' opinion [Kosobudzki et al. 2000, Jędrczak and Haziak, 2005, Meller et al. 2007], C: N ratio $<20$, indicates compost maturity and a preferable $\mathrm{C}: \mathrm{N}$ value is below 15 [Raj and Antil, 2010, Goyal et al. 2005, Ozimek and Kopeć, 2012]. Com- 
paring the content of $\mathrm{P}$ and $\mathrm{K}$, on the basis of $\mathrm{P}_{2} \mathrm{O}_{5}$ and $\mathrm{K}_{2} \mathrm{O}$, with guidelines for organic solid fertilisers [Dz. U. 2008, No 119, item 765] it can be stated that in all composts the potassium content, converted to oxide form, is within the given limit $\geq 0.2 \%$. In the case of oxide form of phosphorus content, only the green waste compost does not satisfy the requirements $\mathrm{P}_{2} \mathrm{O}_{5} \geq 0.2 \%$. Kazanowska and Szaciło [2008], Krzywy-Gawrońska [2010], Lisk et al. [1992] and Zhao et al. [2013] also obtained similar content of phosphorus and potassium, converted to oxide form, above $0.2 \%$, in the compost from sewage sludge and municipal solid waste. According to IUNG [1990] standards for organic soil nutrient resources, the content of phosphorus, potassium and magnesium determined in $\mathrm{HCl}$ at the concentration $0.5 \mathrm{~mol} \cdot \mathrm{dm}^{-3}$ was as follows: very high resources of potassium and magnesium in all examined composts (I class), very high resources of phosphorus in the compost produced in Kołobrzeg and Wardyń Górny (I class) and high content of phosphorus in the compost from Leśno Górne (II class).

Among the determined heavy metals, the concentration of $\mathrm{S}, \mathrm{Pb}, \mathrm{Ni}, \mathrm{Cd}$, in analysed composts did not exceed admissible values listed in the Regulation [Dz. U. 2008, No 119, item 765] and directives [Szpadt and Jędrczak, 2008] for organic and organic-mineral, fertilisers and amendments.

Comparing the obtained results for heavy metal concentration (soluble in $\mathrm{HCl}$ at the concentration $0.5 \mathrm{~mol} \cdot \mathrm{dm}^{-3}$ ) with IUNG recommendations [IUNG 1990] for organic soils, it may be stated that the content of $\mathrm{Cu}, \mathrm{Pb}$ and $\mathrm{Ni}$ in all the examined composts and $\mathrm{Zn}$ in green waste compost is close to natural ( 0 -degree of contamination). The level of $\mathrm{Zn}$ and $\mathrm{Cd}$ in sewage sludge compost and municipal solid waste compost exhibits a slight contamination with these elements (II-degree of contamination). Concentration of $\mathrm{Cd}$ in green waste compost is elevated in relation to the standard values for organic soils (I-degree of contamination).

\section{CONCLUSIONS}

1. Composts produced from sewage sludge and municipal solid waste meet the legal regulations for solid organic fertilisers.

2. The best utilisation properties were found in the sewage sludge compost and the worst in the city green waste.
3. The examined composts do not exceed heavy metal content limits $(\mathrm{Pb}, \mathrm{Ni}$ and $\mathrm{Cd})$ given in the Regulation of the Minister of Agriculture and Rural Development of 18 June 2008 concerning the implementation of The Act on Fertilisers and Fertilisation.

\section{REFERENCES}

1. Baran S., Wójcikowska-Kapusta A., Żukowska G., Bik M. 2009. Changes of the phosphorus, potassium and magnesium content in compost of different maturity. Advances of Agricultural Sciences Problem Issues 537, 25-31.

2. Beesley L., Dickinson N. 2010. Carbon and trace element mobility in an urban soil amended with green waste compost. J. Soils Sediments 10, 215-222.

3. Castaldi P., Santona L., Melis P. 2006. Evolution of heavy metals mobility during municipial solid waste composting. Frasenius Environmental Bulletin 15 (9b), 1133-1140. Retrieved February 21, 2012, from Parlar Scientific Publications database on the World Wide Web http://www.psp-parlar.de.

4. Ciesielczuk T., Rosik-Dulewska Cz., Karwaczyńska U. 2011. Composts from waste as a potential source of organic matter and nutrients in crop productions. Kompostowanie i mechaniczno-biologiczne przetwarzanie odpadów, 108-116 (in Polish).

5. Czekała J., Sawicka A. 2006. Processing of sewage sludge with addend straw and sawdust into a product safe for the environment. Water-EnvironmentRural Areas 6 (2), 41-50 (in Polish).

6. Dziennik Ustaw 2007, No 147, item 1033.

7. Dziennik Ustaw 2008, No 119, item 765.

8. Gondek K., Kopeć M. 2012. Content of selected macro and microelements in composted biodegradable municipal waste. Acta Agrophysica, 19(3), 527-538 (in Polish).

9. Goyal S., Dhull S.K., Kapoor K.K. 2005. Chemical and biological changes during composting of different organic wastes and assessment of compost maturity. Bioresource Technology, 96, 1584-1591.

10. IUNG. 1990. Limits numbers for estimating soil macro and microelement content. Institute of Soil Science and Plant Cultivation Puławy, 44. Puławy 1990 (in Polish).

11. Jasiewicz C., Antonkiewicz J., Baran A. 2010. Assessment of the use of municipal and industrial wastes in agriculture. Polish Journal of Chemical Technology, 9, 3, 15-19.

12. Jędrczak A., Haziak K. 2005. Determination of requirements for composting and other methods of waste biological treatment. Pracownie Badawczo Projektowe „EKOSYSTEM” Sp z o.o., Zielona 
Góra 2005 (in Polish).

13. Jędrczak A., Haziak K. 2005. The characteristic of biodegradable waste. IV-th International Waste Management Forum, Efficiency of waste management, May/June 2005. Poznań-Licheń Stary, Poland (in Polish), 233-245.

14. Kazanowska J., Szaciło J. 2008. The composting of solid waste in DANO composting plane in Suwalki. Environmental protection and natural resources. 35/36, 181-288 (in Polish).

15. Kosobudzki P., Chmarzyński A., Buszewski B. 2000. Sewage Sludge Composting. Pol. J. Environ. Stud.. 9 (4), 243-248.

16. Krzywy-Gawrońska E. 2010. Impact of composts with the participation of municipal sewage sludge on the content of the total forms of copper, manganese and zinc in soil. Polish Journal of Chemical Technology 12 (4), 15-18.

17. Lisk D. J., Gutenmann W. H., Rutzke M., Kuntz H. T., Chu G. 1992. Survey of Toxicants and Nutrients in Composted Waste Materials. Arch. Environ. Contam. Toxicol. 22, 190-194.

18. Manczarski P. 2009. Composting and mechanical biological stabilisation of municipal waste organic fraction. Prace Instytutu Nafty i Gazu 164, 107116 (in Polish).

19. Meller E., Sammel A., Suchenia M. 2007. Morphological composition and fertilising properties of composts produced from organic fraction of municipal waste in ZUO Gorzów Wielkopolski. Zesz. Nauk. Uniwersytetu Zielonogórskiego 133, 305-315 (in Polish).

20. Miaomiao H., Wenhong L., Xingiang L., Donglei W., Guangming T. 2009 . Effect of composting process on phytotoxicity and speciation of copper, zinc and lead in sewage sludge and swine manure.
Waste Management., 29 (2), 590-597.

21. Ozimek A., Kopeć M. 2012. Assessment of biological activity of biomass at different stages of composting process with use of the Oxitop Control measurement. Acta Agrophysica, 19(2), 379-390 (in Polish).

22. Pagans E., Barrena R., Font X., Sánchez A. (2006). Ammonia emissions from the composting of different organic wastes. Dependency on process temperature. Et. al Chemosphere 62, 1534-1542.

23. Raj D., Antil R.S. 2010. Evaluation of maturity and stability parameters of composts prepared from agro-industrial waste. Bioresource Technology 102, 2868-2873.

24. Ribeiro H.M.F., D’almeida Duarte E.F., Baião M., Rola E., Vaz M.C. 1996. An evaluation of three municipal solid wastes composts. In: C. Rodriguez-Barrueco (Ed.), Fertilizers and Environment, 351-353.

25. Sądej W., Namiotko A. 2010. Content of zinc in plants fertilized with municipal solid waste and Urban Green waste composts. J. Elementol., 15(4): 679-692.

26. Szpadt R., Jędrczak A. 008). Guidelines for requirements concerning waste composting, fermentation and mechanical biological treatment (according to legal status for 15December 2008.) Warszawa (in Polish). Retrived May 25, 2011, from Ministerstwo Środowiska http:// www.mos.gov.pl/g2/big/2009 07/ffc492d741b261340b1e263cd1c05c85.pdf.

27. Zhao S., Shang X., Duo L. 2013 Accumulation and spatial distribution of $\mathrm{Cd}, \mathrm{Cr}$, and $\mathrm{Pb}$ in mulberry from municipial solid waste compost following application of EDTA and $\left(\mathrm{NH}_{4}\right)_{2} \mathrm{SO}_{4}$. Environ. Sci. Pollut. Res. 20, 967-975. 